\title{
鋼の連続冷却におけるべイナイト変態の潜伏期について*
}

\author{
清 水 信 善**.田 村今 男***
}

\section{On the Incubation Period for Bainitic Transformation during Continuous Cooling in Steels}

\author{
Nobuyoshi SHImizu and Imao TAMURA
}

\section{Synopsis:}

The process of the consuming incubation period for bainitic transformation during continuous cooling of steels was examined in the relation with consumption of incubation period for ferritic or pearlitic transformation by steels of JIS SUJ2, SCM5, and SNCM8. The main results are as follows:

(1) There is a critical temperature $\left(A_{B}\right)$ at which the consumption of incubation period for bainitic transformation starts during continuous cooling.

(2) The consumption of incubation period for bainitic transformation is progressed independently of any consumption of incubation period for ferritic of pearlitic transformation.

(3) The bainitic transformation behaviour after a change of cooling rate during continuous cooling shows a different manner from that indicated by a usual CGT-diagram of the steel because of the different way in consumption of the incubation period. The estimation method of the transformation behaviour in such a case was explained by using usual CGT-diagram.

\section{1. 緒言}

等温変態線図 (TTT曲線) や連続冷却変態線図 (CCT 曲線）は，合金元素(1) 4)，オーステナイト化条件 (5) 7), 結晶粒度8)9), 熱処理時の外力や压力10) その他種々な条 件 ${ }^{11)}$ １4)によつて変化する。 このことは，フェライト， パーライトおよびベィナイトなどの変態の潜伏期*も上 記の条件によつて変化することを意味する.

しかしフェライトやパーライト变態の潜伏期について はいままでにしばしば議論されているが，ベイナイト変 態については，それが独立した潜伏期をもつものと想像 されるが，それについて明らかに示した研究はないよう である. TTT 曲線ではべイナイト変態のための潜伏期 があることは誰しも認めているであろうが，いままでべ イナイト変態の潜伏期に対して関心が寄せられなかつた ように思われる. 1，2の交献416)17) において, 独立し た潜伏期をもつという考杂が間接的に示されているにす ぎない.

* 潜伏期を核!生成時間，变怨閒始時間，潜伏期洔間などと呼ぶ場合が ある.
著者らは，ベイナイト変態においてもフェライトやパ 一ライト変態とは別に独立した潜伙期をもつという推点 に立つて，それぞれの潜伏期の消費が互いにどのように 影響し合い，また，ベイナイト変態の潜伏期がどのよう に消費されてゆくかについて研究した。さらに，連続冷 却途中で泠却速度を変更した場合のベイナイト变態挙動 についても研究した。

著者らは前報15)で，連続冷却におけるパーライト変態 の潜伏期の消費がその後の冷却における変態挙動や臨界 冷却速度に大きく影響することを明らかにした。したが つて，本研究においてもべイナイト変態の潜伏期の消費 を明らかにすることは，ベイナイトの変態挙動を知るた わの重要な課題であると考えられる.

\section{2. 実 験 方 法}

实験に使用した供試材の化学組成をTable 1 に示す. ここで，S-1 は SUJ 2 に相当する鋼種で，球状化焼な まし（球状炭化物の粒径は平均 $0.5 \mu$ ) を行なつた線材 から $4 \mathrm{~mm} \phi \times 40 \mathrm{~mm}$ の試片を削り出したものである.

* 昭和51年 1 月 27 日受付 (Received Jan. 27, 1976)

** 光洋熱処理 (株) (Koyo Netusyori Co., Ltd., 146 Takochi Yao 581)

*** 京都大学工学部工博 (Department of Metal Science and Technology, Kyoto University) 
Table 1. Chemical compositions of steels (wt \%).

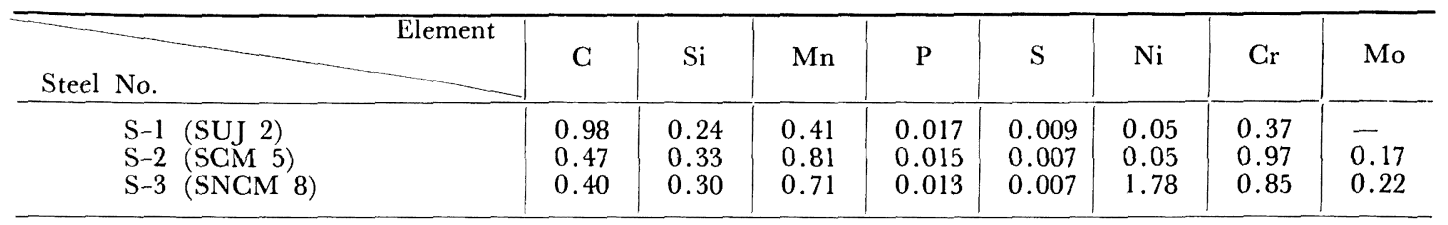

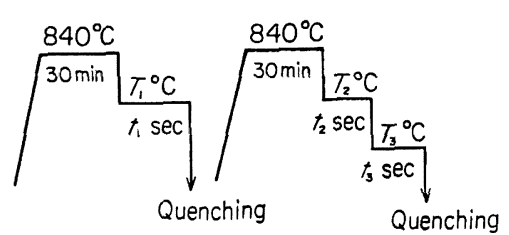

Process $1 \quad$ Process 2

Fig. 1. Schematic diagram showing heat treatment to find incubation period for transformation in S-1 steel.

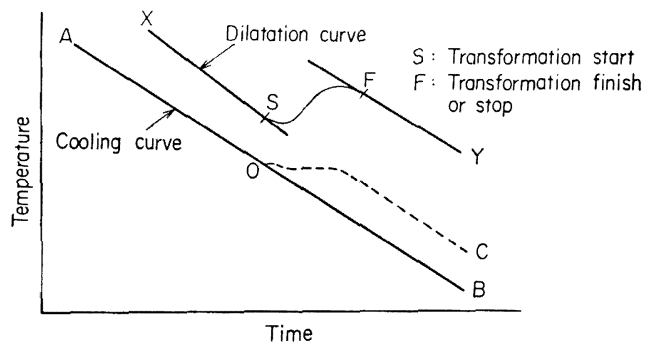

Fig. 2. Schematic diagram showing dilatation and cooling curves to find transformation temperature.

S-2 は SCM 5，S-3 は SNCM 8 に相当する鋼種で, $850^{\circ} \mathrm{C}$ で焼なましを行なつた線材から $3 \mathrm{~mm} \phi \times 10 \mathrm{~mm}$ の試片を削り出したものである。

变態の潜伏期および連続冷却における変態挙動の測定 には，Formastor-F 装置（富士電波工機(株)製）あるい は加熱炉に鉛浴炉を組合せたものを用いた。すなわち， 加熱炉に鉛浴炉を組合せた場合は Fig. 1 に示すように 脱炭を防止するため試片を木炭中でオーステナイト化し たのち，種々な温度の鉛浴に投入してその温度に種々な 時間等温保持したのち，5\%食塩水に焼入して組織の凍 結を行なつた. そして, 硬さの測定と組織の観察よりこ の鋼の等温变態の潜伏期を求めた.さらに，鉛浴を二つ 使つて，種々な温度の鉛浴に投入してその温度に種々な 時間等温保持することによつて潜伏期を消費し, 直ちに $500^{\circ} \mathrm{C}$ 以下の種々な温度の別の鉛浴に投入してその温度 に等温保持したのち，5\%食塩水に焼入して組織の凍結 を行なつた。 そして，前述と同じ方法で潜伏期を求め
た。

Formastor-F の場合は Fig. 2 に示すように，連続冷 却途中で変態熱のため泠却速度が变化しないように調節 した。すなわち，連続冷却 $\mathrm{A} \rightarrow \mathrm{B}$ で示す途中 $\mathrm{O}$ 点で変態

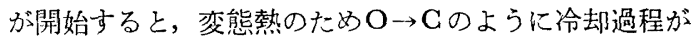
変化するのが普通である. しかし，本研究の変態挙動の 解析を容易にするため, 冷却速度が $\mathrm{A} \rightarrow \mathrm{O} \rightarrow \mathrm{B}$ で示すよ うに一定になるように強制的に調節した。また， $\mathrm{X} \rightarrow \mathrm{Y}$ で示す曲線は熱膨脹の変化曲線で， $\mathrm{S}$ 点は変態開始， $\mathrm{F}$ 点は変態中止または完了を示す．熱膨脹の変化と硬さの 测定および組織の観察から变態挙動を求めた。また，連 続冷却途中で冷却速度を変更する場合は, Formastor-F に数值制御装置を組合せる方法を用いた。

硬さの測定は微小硬度計とロックウェル $\mathrm{C}$ スケールを 使用した、組織観察のための腐食液には $5 \%$ ケイタルを 使用した。

\section{3. 実験結果と考察}

\section{1 パーライトの潜伏期の消賽がベイナイトの潜伏期 に与える影響}

$840^{\circ} \mathrm{C} \times 30 \mathrm{~min}$ でオーステナイト化した鋼 S-1 の等 温変態の潜伏期を求めた結果を Fig. 3 に示す.ここで 曲線の点線で示した部分は推定線であり，パーライト変 態の潜伏期とべイナイト変態の潜伏期はそれぞれ別々の C曲線を示している. いま，ベイナイトの $\mathrm{C}$ 曲線の最高

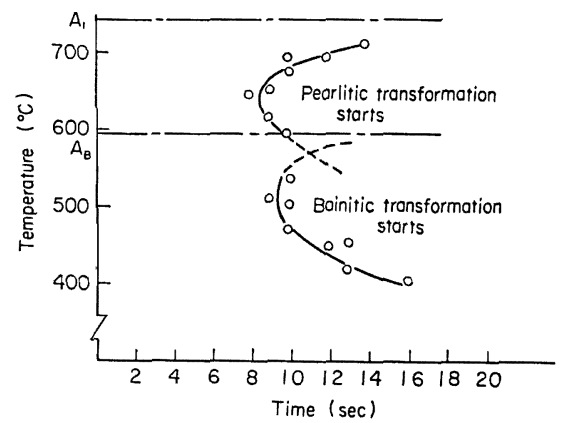

Fig. 3. Incubation time to start for isothermal transformation of austenite in S-1 steel at various temperatures below $A_{1}$, austenitized at $840^{\circ} \mathrm{C}$ for $30 \mathrm{~min}$. 


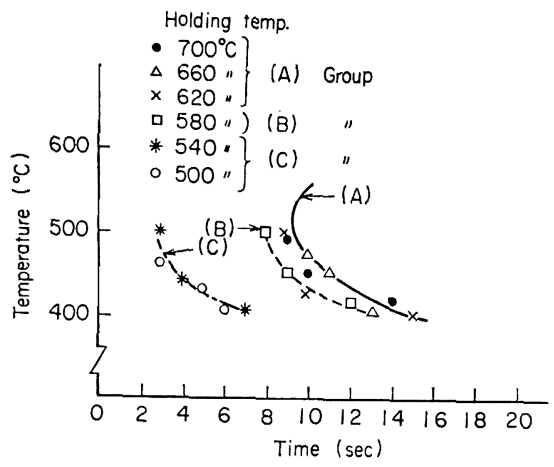

Fig. 4. Influence of $6 \mathrm{sec}$ holding at a temperature above isothermal transformation temperature on the incubation period for isothermal bainitic transformation of S-1 steel, austenitized at $840^{\circ} \mathrm{C}$ for $30 \mathrm{~min}$. No reduction of incubation period is observed when held at 700,660 , and $620^{\circ} \mathrm{C}$, whereas holding at 580,540 and $500^{\circ} \mathrm{C}$ is observed to reduce the incubation period.

温度（曲線の点線部分が然限大の時間になつたときの温 度）を $\mathrm{A}_{\mathrm{B}}$ と定める。

次に，種々な温度での替伏期の消費がベイナイト変態 の潜伏期によ゙のような影響を与えるかを明らかにするた め, 同一オーステナイト化後, 種々な温度に急冷してそ の温度で $6 \mathrm{sec}$ 等温保持することによつて潜伏期を消频 したのち， $500^{\circ} \mathrm{C}$ 以下の種々な温度に等温保持してベイ ナイト変態の潜伏期を求めた。 その結果を Fig. 4 に示 す. Fig. 4 において，700，660，620 $\mathrm{C}$ の場合は曲線 $\mathrm{A}$ で示すように, 当初 Fig. 3 で求めたときの潜伏期と大 差がない結果を示したこのことは， $620^{\circ} \mathrm{C}$ 以上の温度 で潜伏期を消費しても，ベイナイト変態の潜伏期には変 化がないことを示しているすすなわち， $620^{\circ} \mathrm{C}$ 以上での 潜伏期は Fig. 3 からわかるようにパーライトの潜伏期 である.したがつて，パーライト変態の潜伏期の消費は ベイナイト变態の潜伏期にはほとえど影響を与えないこ とを示唆したものである。

しかし，580 $\mathrm{C}$ になると曲線 Bで示すようになり，ま た，540 $\mathrm{C} ， 500^{\circ} \mathrm{C}$ になると曲線Cで示すようにいずれ も当初の潜伏期より短時間になつている. このことは, これらの温度での潜伏期の消費はベイナイト変態の潜伏 期に影響を与えることを示すものである。立た，540， $500^{\circ} \mathrm{C}$ の場合はこの温度で潜伏期を消費された分だけ， それ以下の温度でのベイナイト変態の潜伏期が短くなつ ていることがうかがわれる。

以上の結果から，この鋼のベイナイト変態の潜伏期に

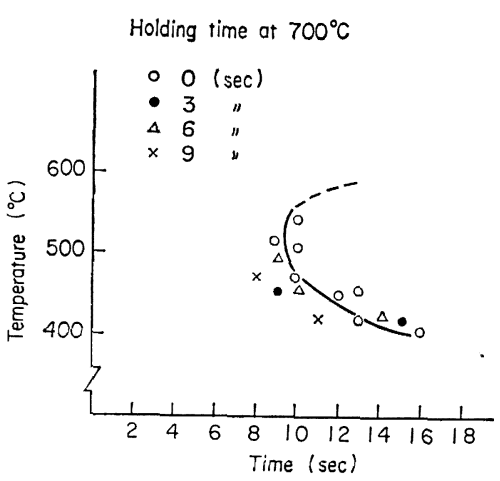

Fig. 5. Influence of holding time at $700^{\circ} \mathrm{C}$ on the incubation period for isothermal bainitic transformation of S-1 steel, austenitized at $840^{\circ} \mathrm{C}$ for $30 \mathrm{~min}$.

影響を与えるのは， $620 〜 580^{\circ} \mathrm{C}$ の間のある一定の温度 以下で潜伏期を消費した場合である．すなわち，Fig. 3 で仮定として示した温度 $A_{B}$ と Fig. 4 で得た温度 620 〜 $580^{\circ} \mathrm{C}$ の間のある一定温度とはほぼ一致した位置にあ る.このことから, ベイナイト変態の潜伏期の消費が起 こるのは温度 $\mathrm{A}_{\mathrm{B}}$ 以下であることがわかる。

また， $700^{\circ} \mathrm{C} て ゙ の$ 等温保持時間を $0 ， 3 ， 6 ， 9 \mathrm{sec}$ と変 えることによつて，パーライト変態の潜代期の消費量を 変えた場合のベイナイト変態の潜伏期を求めた結果を

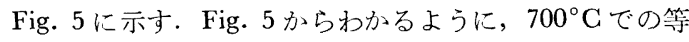
温保持時間が変化しても（ただし，等温保持時間はパー ライトの変態開始時間以内とする. 変態が開始時間以上 になるとパーライト変態の潜伏期を全部消費してしま い，変態による影響がでてきて複雑になる）ベイナイト 变態の潜伏期はほとえど变化しない.このことは前述の Fig. 4 の結果と同じように, ベイナイト変態の替伏期は パーライト変態の潜伏期の消費には影響されず，しかも ベイナイト独自の潜伏期をもつていることを示したもの である。

以上の結果から， $A_{B}$ はベイナイト変態の潜伏期が消 費される最高の温度であると定義される。

\section{$3 \cdot 2$ フェライトの潜伏期の消費がベイナイトの潜伏期} に与える影響

フェライト変態の潜伏期の消費が，ベイナイト変態の 潜伏期にどのような影響を与えるかについて，鋼 S-3を 用いて調べた。

鎆 S-3 $850^{\circ} \mathrm{C} \times 5 \mathrm{~min}$ のオーステナイト化後 650 ${ }^{\circ} \mathrm{C}$ まで急冷してこの温度で等温保持して潜伏時間定求

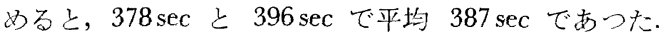
そして，この潜伏期の後にフェライトが析出していたの 
で，これはフェライトの潜伏期である(図は省略する)こ とが知られた. また, 同じオーステナイト化後 $450^{\circ} \mathrm{C}$ まで急冷してこの温度で等温保持して潜伏時間を求める

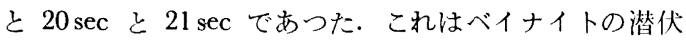
期である.

次に，同じオーステナイト化後 $650^{\circ} \mathrm{C}$ まて急冷し， この温度で $350 \mathrm{sec}$ 等温保持してから（このときフェラ イトの潜伏期は約 $90 \%$ 消費される), 直ちに $450^{\circ} \mathrm{C}$ ま で急冷してこの温度で等温保持してベイナイト变態まで

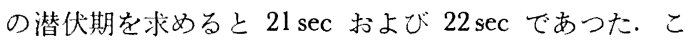
れは前者の $20 \mathrm{sec}$ および $21 \mathrm{sec}$ の結果とほぼ同じであ る.この結果から, フェライト変態の潜伏期の消郿はべ イナイト変態の潜伏期にほとえど影響を与えないことが わかる. 鋼 S-3 の等温変態曲線において, $650^{\circ} \mathrm{C}$ はフ ェライト変態の潜伏期の息に当たる温度であり， $450^{\circ} \mathrm{C}$ はベイナイト変態の潜伏期の罴に当たる温度である.

HigGINs ら ${ }^{16)}$ は, En26 鋼においてオーステナイト化 後 $710 \sim 600^{\circ} \mathrm{C}$ の温度に等温保持することによつて 320 ${ }^{\circ} \mathrm{C}$ でのベイナイト变態の開始が促進されると報告して いる，著者らの結果と多少異なるのは，著者らが用いた 鋼より TTT 曲線でのフェライトおよびパーライト段階 が著しく長時間のものであり，また，710～ $600^{\circ} \mathrm{C}$ での 保持時間も著者らより長時間であること, そして, 著者 らがベイナイト段階の是に当る温度の $450^{\circ} \mathrm{C}$ でのベイ
ナイト変態の潜伏期の変化它求めたのに対して, 彼らは 鼻に当る温度 $\left(\operatorname{En} 26\right.$ 鋼で $\left.450^{\circ} \mathrm{C}\right)$ より著しく低い温度 の $320^{\circ} \mathrm{C}$ で行なつているためと考えられる.さらに， 合金元素の影響も考えられるので，これらの点について は，今後の研究を待たねばならない.

\section{3 連続泠却途中で冷却速度を変更した場合のベイナ イト変態挙動と CCT 曲線の関保}

鋼 S-2 を $850^{\circ} \mathrm{C} \times 10 \mathrm{~min}$ オーステナイト化したと きの CCT 曲線*と, 同じオーステナイト化後 $3.5^{\circ} \mathrm{C} /$ sec で連続冷却する途中で冷却速度を $10^{\circ} \mathrm{C} / \mathrm{sec}$ に変更 した場合の変態挙動（ここでは硬さの変化で表す）を求 めた結果を Fig. 6 に示す. Fig. 6 において，オーステ ナイト化温度 $\mathrm{T}_{\mathrm{A}}$ から種々の冷却速度で常温まで冷却し たときのそれぞれの硬さを（）内に示す.そして，才 ーステナイト化温度 $\mathrm{T}_{\mathrm{A}}$ から $3.5^{\circ} \mathrm{C} / \mathrm{sec}$ の冷却速度で 泠却する途中で泠却速度を $10^{\circ} \mathrm{C} / \sec$ に変更して常温ま で冷却したときのそれぞれの硬さを○内に示す.

Fig. 6 に扎いて，たとえばオーステナイト化温度 $\mathrm{T}_{\mathrm{A}}$ から $3.5^{\circ} \mathrm{C} / \mathrm{sec}$ の冷却速度で泠却すると, ベイナイト 変態を起こし， $\mathrm{T}_{\mathrm{X}}$ 点でベイナイト変態は中止され, さ らに冷却して行くと Ms 点に達してマルテンサイト变態 を起こして常温にいたる.このときの硬さは Hv 496 で

* 一般に CCT 曲線の時間暔は対数目盛で表しているが，ここでは解 析を容易にするため等間隔の目盛で表わすととにした。

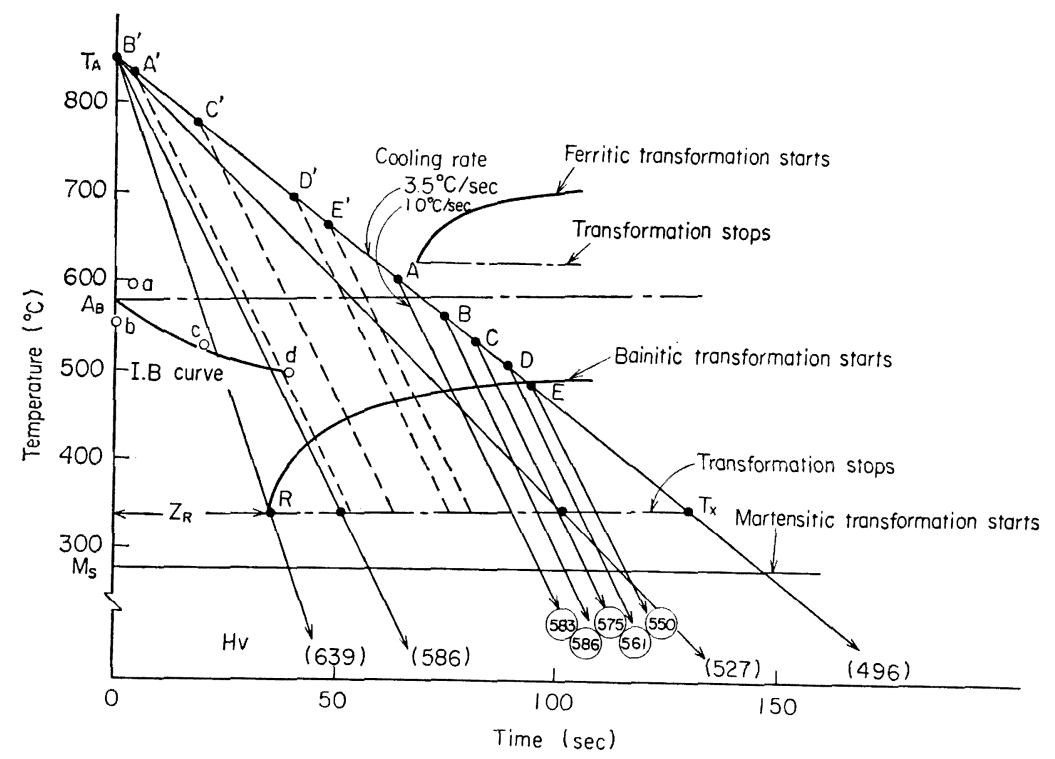

Fig. 6. CCT diagram for S-2 steel and transformation behaviors after discontinuous change of cooling rate at several points of $\mathrm{A}, \mathrm{B}, \mathrm{C}$ during continuous cooling $\mathrm{T}_{\mathrm{A}}$ to $\mathrm{T}_{\mathrm{X}}$, austenitized at $850^{\circ} \mathrm{C}$ for $10 \mathrm{~min}$. 
ある・

いま, $\mathrm{T}_{\mathrm{A}}$ から $3.5^{\circ} \mathrm{C} / \mathrm{sec}$ で泠却していく途中の点 $\mathrm{A}\left(600^{\circ} \mathrm{C}\right), \quad \mathrm{B}\left(550^{\circ} \mathrm{C}\right), \quad \mathrm{C}\left(525^{\circ} \mathrm{C}\right), \quad \mathrm{D}\left(500^{\circ} \mathrm{C}\right), \quad \mathrm{E}$ $\left(475^{\circ} \mathrm{C}\right)$ で，それぞれ冷却速度を $10^{\circ} \mathrm{C} / \mathrm{sec}$ に変更して 常温まで泠却すると，硬さはそれぞれ Hv 583，586， 575，561，550 となる. これらの硬さの挙動は，CCT曲 線で示されるものとは異なつているととがわかる.

そこで，冷却途中の $\mathrm{A}, \mathrm{B}, \mathrm{C} \cdots \cdots \cdot$..点で冷却速度を变更 したときの変態挙動を CCT 曲線で知るため, 変更後の 冷却速度で泠却したときのそれぞれの硬さの值を CCT 曲線の变態中止線の同じ硬さの位置にプロットし，その 位置から变更後の冷却曲線に平行線を引いて $\mathrm{T}_{\mathrm{A}}-\mathrm{T}_{\mathrm{X}}$ 線

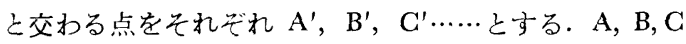
……で泠却速度を变更し, 変更後の冷却速度で冷却した ときに示す実質の变態挙動は，それぞれ $\mathrm{A}^{\prime} ， \mathrm{~B}^{\prime}, \mathrm{C}^{\prime} \cdots \cdots$ から変更したものとしてこの CCT 曲線を用いて判断し てもよいと思われる。

Fig. 6 に打いて, 冷却途中の点 A, B , C ……温度上 これらに対応する点 $\mathrm{A}^{\prime}, \mathrm{B}^{\prime}, \mathrm{C}^{\prime} \cdots \cdots$...時間を結えだ点を それぞれ $a, b, c \cdots \cdots$ とする. これら $a, b, c \cdots \cdots .$. 点を結え でできた曲線を I.B curve と名付ける.ただし I.B curve は, A, B, C……点が変態開始線に達するまでの温 度範囲とする．変態が開始すると潜伏期は消費されてし まうからである。

すでに著者らは,パーライト変態において連続冷却途 中で泠却速度を变更したとき，その変態挙動は，冷却途 中までに消費したパーライトの潜伙期に関係しているこ とを明らかにした イトの潜伏期の消費は， $\mathrm{A}_{1}$ 变態点から開始する潜伏期 の消費曲線（I.P curve）によつて示されることを提唱 した ${ }^{15)}$.これと同様に Fig. 6 に示した I.B curveは, $\mathrm{Z}_{\mathrm{R}}$ を全潜伏期(すなわち， $\mathrm{Z}_{\mathrm{R}}=1$ ) として， $\mathrm{T}_{\mathrm{A}}$ から $\mathrm{T}_{\mathrm{X}}$ まで連続冷却したときのベイナイトの潜伏期の消費を示 す曲線上考えられる。すなわち, 連続冷却の場合のベイ ナイトの潜伏期の消費は, 温度 $\mathrm{A}_{\mathrm{B}}$ から開始されること を示している.ここで， $\mathrm{Z}_{\mathrm{R}}$ は $\mathrm{T}_{\mathrm{A}}$ から䧗界冷却速度で 冷却したときのべイナイト変態開始点 $\mathrm{R} に$ 達するまでの 時間である.

\section{4 連続冷却におけるベイナイトの潜伏期の消費}

連続冷却に打けるパーライトの潜伏期の消費について は，著者らによつてすでに報告されている、すなわち， パーライトの等温潜伏期を $Z_{p}(T)$, 連続冷却速度を $X$ （T）とすれば，連続冷却によつて温度 $\mathrm{T}_{\mathrm{n}}$ まで冷却し たときのパーライトの潜伏期の消費量 $I . P$ は

$$
\begin{aligned}
& \text { I. } P_{(\mathrm{Tn})}=\int_{\mathrm{A}_{1}}^{\mathrm{Tn}} \frac{d X(T) / d T}{Z_{p}(T)} d T \\
& \text { （ただし，I.P } \left.P_{(\mathrm{Tn})} \leqq 1\right)
\end{aligned}
$$

で示される。

一方，連続冷却におけるベイナイトの潜伏期の消費は Fig. 4, Fig. 5, Fig. 6 で示した結果から明らかなごと く，フェライトやパーライトの潜伏期の消費と無関係の ものである.すなわち，ベイナイトの等温潜代期を $Z_{B}$ $(T)$, 連続冷却速度を $X(T)$ とすれば, 連続冷却によ つて温度 $\mathrm{T}_{\mathrm{m}}$ まで泠却されたときのベイナイトの潜伏 期の消費量 $I . B$ は

$$
\begin{aligned}
I . B_{(\mathrm{Tm})}=\int_{\mathrm{A}_{\mathrm{B}}}^{\mathrm{T}_{\mathrm{m}}} \frac{d X(T) / d T}{Z_{B}(T)} d T \cdots \cdots \cdots \cdots \\
\left(\text { ただし, } I . B_{(\mathrm{Tm})} \leqq 1\right)
\end{aligned}
$$

で示されることになる.

(2)式で示すように, 連続冷却におけるべイナイト変 態の潜伏期の消費は温度 $A_{B}$ から開始され，また，その 消費量はべイナイト独自の等温潜伏期に関係している.

Fig. 6 で示した $I . B$ curve は（2）式を用いて計算した ものと同じになると思われるら。.ただし $A_{B}$ は鋼種など によつて変化する.

MANNING ${ }^{17)}$ らが連続泠却に抄ける潜伏期の消費を等 温潜伏期から求めるに際して, ベイナイトについてはパ ーライト拈よびフェライトとは区別して取扱つているこ とは著者らの示したことと一致する。しかし，彼らはへ ナイトの潜伏期の開始温度を計算の便宜上から $1130^{\circ} \mathrm{F}$ $\left(610^{\circ} \mathrm{C}\right)$ の一定に定めている. しかしながら等温変態の 潜伏期において，フェライトおよびパーライトの曲線と ベイナイトの曲線が，交錯している場合と分踓している 場合がある1819)ことからも理解できるように, ベイナイ 卜変態の潜伏期の消費が開始される温度を鋼種によらず 一定の $1130^{\circ} \mathrm{F}$ とするよりも，著者らの示した $A_{B}$ とす る方が妥当と考えられる。また，彼らはTTT曲線にお いて，ベイナイトが独自の曲線をもつていることについ ては何らふれていない。

一方, AARONSON ${ }^{4)}$ はベイナイト変態が開始する最高 の温度 $\mathrm{B}_{\mathrm{S}}$ の存在することを提示し， $\mathrm{B}_{\mathrm{S}}$ は共析温度よ り $100 \sim 300^{\circ} \mathrm{C}$ 以下にあると説明している。また， ZE$\left.{ }^{N E R}{ }^{20}\right)$ は $B_{S}$ は $T_{O}$ にほぼ等しい子説明している。ここ に, $\mathrm{T}_{\mathrm{o}}$ はその鋼のオーステナイトの自由エネルギーと， そのオーステナイトと同じ浱度のフェライトの自由エネ ルギーが等しくなる温度である。其析鋼のようにオース テナイトがハーライトあるいはベイナイトのいずれかに 変態する場合は $\mathrm{B}_{\mathrm{S}}$ の存在を認めやすいが，フェライト の変態が先行して起こりその後パーライトあるいはベイ 
ナイト変態をする場合は変態組織が複雑になり，それが パーライトであるかベイナイトであるかの判断も明らか でない場合が起こり，そのため $\mathrm{B}_{\mathrm{S}}$ の存在について充分 な説明ができないことを認めている4). $\mathrm{T}_{0}$ 以下の温度で 無拡散变態の駆動力が発生するから， $\mathrm{T}_{\mathrm{O}}$ をベイナイト 变態開始の最高温度とすることは物理的意味において非 常に明確であるが，現象はそれほど単純ではない。

著者らの示した $A_{B}$ はベイナイト変態の潜伏期をもと にして定義したもので，その物理的意味については今後 の研究をまたね䞏ならない，それ故，今ここで $\mathrm{A}_{\mathrm{B}}, \mathrm{B}_{\mathrm{S}}$ および $\mathrm{T}_{\mathrm{O}}$ の是非を簡単に論ずることは早計であるう.

\section{5 冷却速度変更によるベイナイト变態挙動を GCT 曲線から作図的に求める方法}

連続冷却途中で泠却速度を変更した場合のベイナイト の变態挙動を CCT 曲線を使つて作図的に求好方法に ついて Fig. 7 によつて述べる. Fig. 7 において， $\mathrm{T}_{\mathrm{A}}$ から冷却速度 $\alpha$ で泠却したときのべイナイト変態挙動は $\mathrm{T}_{\mathrm{A}}-\mathrm{A}$ 線で示される. しかし, 冷却の途中Q点で泠却速 度を $\beta$ に変更した場合の泠却は Q-B 線で示されるが， その变態挙動をこのままの曲線で示すとすると $\mathrm{Q}^{\prime}-\mathrm{C}$ 線 で示されることになる。この方法はすでに前報15)におい て，パーライト変態について述べたすなわち， $\mathrm{T}_{\mathrm{A}}$ か ら $\alpha$ で泠却される場合のベイナィトの潜伏期の消費量を 種々の温度について (2)式によつて求める， $Z_{R}$ を全潜 伏期として, 各温度の潜伏期の消費量を図上にプロット して I.B curve を作成する. Q 点から時間軸化行線 を引き $I . B$ curve と交る点を求め, その点から温度軸に 平行線を引き $\mathrm{T}_{\mathrm{A}}-\mathrm{A}$ 線と交わる点が $\mathrm{Q}^{\prime}$ 点である. $\mathrm{Q}^{\prime}$ 点加ら Q-B 線に平行線を引くと $\mathrm{Q}^{\prime}-\mathrm{C}$ 線が得られる.

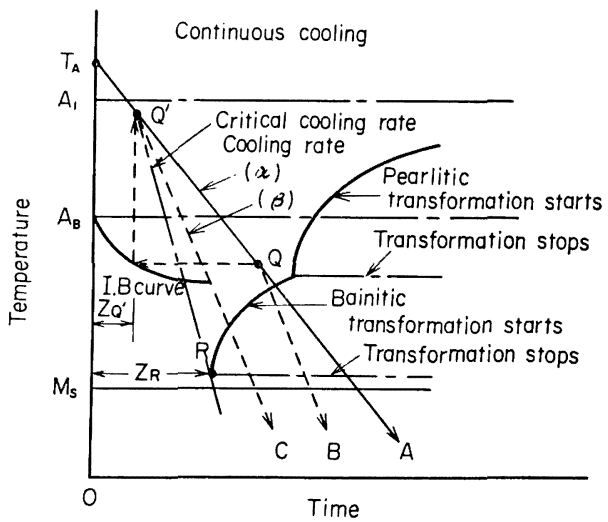

Fig. 7. Schematic diagrams showing a method to find bainitic transformationIbehavior when the cooling rate is discontinuously altered during the continuous cooling.
また， $\mathrm{Q}$ 点からの臨界冷却速度は $\mathrm{Q}^{\prime}-\mathrm{R}$ 線で示され ることになる。ここで $\mathrm{R} は \mathrm{~T}_{\mathrm{A}}$ から臨界冷却速度で冷却 したときのべイナイト变態開始点である.いま，Q点か らの臨界冷却速度を $\gamma$ とすると, 潜伏期の消費量が 1 亿 なつたとき变態が開始するから（2）式は次のように なる。

$$
\frac{1}{\alpha} \int_{\mathrm{T}_{\Delta}}^{\mathrm{T}_{\mathrm{Q}}} \frac{d T}{Z_{B}(T)}+\frac{1}{\gamma} \int_{\mathrm{T}_{\mathrm{Q}}}^{\mathrm{T}_{\mathrm{R}}} \frac{d T}{Z_{B}(T)}=1
$$

(3)式で求めた $\gamma$ と $Q^{\prime} \rightarrow \mathrm{R}$ 線で示した冷却速度はほぼ 一致することは前報15)から理解できる.

以上，連続冷却におけるべイナイトの潜伏期について 述べたが，連続冷却途中でフェライトをたはセメンタイ 卜などの析出変態があると，ベイナイト变態の潜伏期は かなり変化するので (2)，(3)式は成立しないことにな る.このことは次報にゆずる。また，過共析鋼を球状炭 化物の存在する温度籁囲でオーステナイト化した場合,

Fig. 4, Fig. 5 におけるパーライト変態の潜伏期の消費 段階で, 残存炭化物の成長によりマトリックスの $\mathrm{C}$ 濃度 が変化して，ベイナイトの潜伏期に影響を与える可能性 が考えられる.しかし，本研究のようにオーステナイト 化によつておよそ半分 $(0.5 \% \mathrm{C})$ に当るの炭化物を固溶 した場合の残存炭化物の成長は，パーライト変態以前で はほとんど起こらない21)ので残存炭化物の影響は非常に 小さいと考えられる.

\section{4. 結言}

フェライトおよびパーライト変態の潜伏期の消費とべ イナイト変態の潜伏期の関係, 連続冷却におけるべイナ イト变態の潜伏期の消費，および連続冷却途中で泠却速 度を変更した場合のベイナィト变態挙動について研究し た結果次のようなことが明らかになつた。

（1）べイナイト変態の潜伏期は，フェライトおよび パーライト变態の潜伏期の消費にほとんぞ無関係で独自 の潜伏期をもち，独自の消費の挙動を示す．

（2）連続冷却において，ベイナイト変態の潜伏期の 消費が開始する独自の温度 $\mathrm{A}_{\mathrm{B}}$ が存在する.

（3）連続冷却途中で泠却速度を变更した場合のベイ ナイト変態挙動は, 通常の CCT 曲線で示される変態挙 動とは異つた挙動を示す.

（4）冷却速度变更後の变態挙動を CCT 曲線から推 定する方法を提案した。 それは，ベイナイトの臨界泠却 速度で泠却したときの潜伏期を全潜伏期として, 冷却速 度変更までに消費した潜伏期量だけ経過したものとみな しそこから変更した泠却速度で泠却曲線をひくことに より達成できる。 
終りに，本研究を行なうにあたり協力していただいた 富士電波工機 (株) 取䋨役技術部長峰松裕行氏に謝意を表 します。

\section{交献}

1) 村上, 今年：日本金属学会誌，6 (1942)，p. 145

2 ）日本熱処理技術協会編：熱処理の基礎，（1） (1970), p. 192

3 ) E. C. Bain and $H$ W. Paxton: Alloying Elements in Steel, ASM (1961)

4) H. I. Aaronson: Inst. Metals Monograph No. 33 (1969), p. 270

5 ) 近藤：日本金属学会誌， 7 (1943), p. 193

6 ) 須藤, 本間: 日立評諭, 40 (1958) 6, p. 749

7 ) J.F. Libsch, W. P. Ghuang, and $W . J$. Murphy: Trans. ASM, 42 (1950), p. 121

8 ）日本鉄鋼協会編：鋼の熱処理 5 版，(1969), p. 4

9 ) R. H. Авовм: Welding J., 20 (1940), p. 414
10）金沢：日本金属学会誌，26 (1962)，p. 9

11) E. S. Davenport: Trans. ASM, 29 (1939), p. 837

12) 大和久: $\mathrm{S}$ 曲線, (1969), p. 15 [日刊工業]

13）鉄鋼工学㛵座：鋼の熱処理技術，(1969), p. 41

14）金子：金属熱処理原論，(1967)，p. 157 [丸蹇]

15）清水，田村：鉄と鋼，61 (1975)，p. 2375

16) G. T. Higgins and H.J. Axon: JISI, 198 (1961), p. 46

17) G. K. Manning and C. H. Lorig: Trans. AIME, 167 (1946), p. 442

18) $R$. F. Hehemann and $A$. R. Troiano: Metal Prog., 70 (1956), p. 97

19）日本熱処理技術協会編：熱処理の基礎，（1） (1970), p. 176

20) C. Zener: Trans. Amer. Inst. Min. Met. Eng., 167 (1946), p. 550

21）中野, 木下：私信 